\title{
Estimated prevalence of Hepatitis C Virus infection in Canada, 2011
}

\author{
Trubnikov $\mathbf{M}^{1^{*}}$, Yan $\mathrm{P}^{1}$, Archibald $\mathrm{C}^{1}$ \\ ${ }^{1}$ Centre for Communicable Diseases and Infection Control, Public Health Agency of Canada, Ottawa, ON \\ *Corresponding author: Maxim.Trubnikov@phac-aspc.gc.ca
}

Abstract

Background: Prevalence estimates contribute to our understanding of the magnitude of a particular health condition and in planning appropriate public health interventions.

Objective: To estimate the prevalence of chronic Hepatitis C virus (HCV) infection, anti-HCV-positive status (anti$\mathrm{HCV}$ ) and the proportion of undiagnosed HCV infections in Canada.

Methods: A combination of back-calculation and workbook methods was used. The back-calculation method estimated prevalent chronic HCV infection and the proportion undiagnosed using the Canadian Cancer Registry's data on hepatocellular carcinoma reported between 1992 and 2008 and the Canadian Notifiable Disease Surveillance System's data on Hepatitis C virus (HCV) cases reported between 1991 and 2009 in a Markov multistate disease progression model with parameters adjusted to Canada. The workbook method divided the total population of Canada into population subsets and developed estimates of population size and anti-HCV prevalence for each. Sub-population size estimates were multiplied by anti-HCV prevalence measures to calculate the prevalence of anti-HCV by sub-population. A measure of spontaneous clearance was used to estimate the number of persons with chronic HCV from estimates of the number of anti-HCV-positive persons.

Results: The back-calculation method estimated the prevalence of chronic HCV infection at $0.64 \%$ and the proportion of undiagnosed chronic HCV infection at $44 \%$ in 2011. The workbook method estimated the anti-HCV prevalence at $0.96 \%$ (plausibility range: $0.61 \%$ to $1.34 \%)$ and chronic HCV infection at $0.71 \%(0.45-0.99 \%)$.

Interpretation: By combining mid-point estimates from both methods, it is estimated that between $0.64 \%$ to $0.71 \%$ of the overall Canadian population was living with chronic HCV infection in 2011 and $44 \%$ of these individuals were undiagnosed.

\section{Introduction}

Chronic Hepatitis C virus (HCV) infection affects an estimated $3 \%$ of the world's population (1). Approximately three out of four persons with acute HCV infection will not clear the virus spontaneously within six months and will develop chronic HCV infection with an array of long-term sequelae (2). The diagnosis of HCV infection is usually based on identifying antibodies to HCV (anti-HCV) and/or the viral material (i.e., HCV ribonucleic acid) (3) alongside certain liver function enzyme tests (4). A positive anti-HCV test result indicates past or current HCV infection since the HCV antibodies may remain after the virus has cleared. A positive HCV-RNA test suggests a current infection which may be acute or chronic, with chronic HCV infection being defined as a positive HCV-RNA test for more than six months since the presumed infection date.

National estimates of prevalence contribute to our understanding of the magnitude of a particular condition and can help in planning appropriate public health interventions (5). The prevalence of anti-HCV-positive persons in Canada was estimated at $0.78 \%$ of the total Canadian population in 2007 , of whom $21 \%$ were considered not diagnosed at the time (6). Based on the data from Cycles 1 and 2 of the Canadian Health Measures Survey (2007-2011), Rotermann and colleagues estimate anti-HCV seroprevalence in the range of $0.3 \%$ to $0.9 \%$ with a mid-estimate of $0.5 \%$. Approximately $70 \%$ of persons who tested anti-HCV-positive reported that they did not have Hepatitis $\mathrm{C}(7)$. 
However, the Canadian Health Measures Survey did not cover non-household populations with a higher HCV burden (8) (e.g., prison inmates, homeless persons and residents of health care facilities) and, with a response rate of just above $52 \%(7)$, the Survey may have under-sampled household populations that were highly affected by HCV (e.g., people who use injection drugs (IDU), chronically ill persons on haemodialysis and immigrants who do not speak English or French). Therefore, the analysis by Rotermann and colleagues (7) likely underestimated the true anti-HCV seroprevalence in Canada.

Given the length of time since the last HCV prevalence estimates were developed in Canada (6) and the potential limitations of the analysis by Rotermann and colleagues (7), this review sought to update estimates of the prevalence of chronic HCV infection, anti-HCV-positive persons and the proportion of undiagnosed cases of chronic HCV infection in Canada.

\section{Methods}

Estimates of the prevalence of chronic HCV infection and anti-HCV-positive persons and the proportion of undiagnosed cases of chronic HCV infection in Canada were developed using a combination of back-calculation (9) and workbook (10) methods.

Back-calculation uses the observed occurrence of subsequent events to make inference about the incidence of the initiating events in the past that lead to them. This method was recently adopted to estimate the incidence of HCV infection in France (11) and England (12), where reported data on HCV-associated hepatocellular carcinoma and a Markov multi-state disease progression model were used to back-calculate the historical HCV incidence. We used a back-calculation method with Canadian Cancer Registry's data on hepatocellular carcinoma reported between 1992 and 2008 and a Markov multi-state disease progression model with parameters adjusted to Canada $(13,14)$ to estimate chronic HCV infection prevalence and the proportion of undiagnosed HCV infections in 2011. The prevalence of chronic Hepatitis C per 100 population was estimated with data stratified by 5-year birth cohort according to the date of birth. The overall prevalence was estimated using the same model with all birth cohorts combined. Another back-calculation process with data from the Canadian Notifiable Disease Surveillance System (CNDSS) on HCV cases reported between 1991 and 2009 was run in parallel to ensure the reliability of the estimates of the former. As record-level HCV data from CNDSS was only available for six Canadian provinces and territories that account for $88 \%$ of the Canadian population, estimates from the backcalculation were extrapolated to the whole Canadian population.

A workbook method was used to estimate the number of prevalent and undiagnosed anti-HCV-positive persons in Canada in 2011. Using this method, population size estimates were multiplied by anti-HCV seroprevalence measures (anti-HCV) to produce estimates of prevalent anti-HCV-positive persons. A value of $26 \%$ was used to describe the population's spontaneous HCV clearance and to estimate the chronic HCV infection prevalence from an estimate of anti-HCV-positive persons (15). Then, estimates of prevalent anti-HCV-positive persons were multiplied by the proportion of undiagnosed chronic HCV infection from the back-calculation method to produce the numbers of potentially undiagnosed persons.

The total population of Canada was divided into population subsets and size and anti-HCV prevalence estimates were developed for each subset population. Population size estimates were developed using data from published literature and a custom tabulation of the Cycle 1 and 2 data from the Canadian Health Measures Survey (Unpublished data. Public Health Agency of Canada, available from the author upon request). Sources are referenced in Table 1.

The MEDLINE, EMBASE, GLOBAL HEALTH, SCOPUS and PROQUEST PUBLIC HEALTH databases were searched for anti-HCV prevalence measures in the populations of interest in Canada and other developed countries through relevant papers published from 2000-2013 in English or French. Bibliographies of identified studies were also searched for relevant articles in addition to the electronic resources of Statistics Canada, Citizenship and Immigration Canada, Correctional Service Canada, the Public Health Agency of Canada (PHAC) and the Internet. Requests for information were sent to Canadian experts working in the fields of migration health, prison studies, substance abuse, mathematical modelling and Hepatitis C epidemiology. 
During the review, anti-HCV seroprevalence measures were ranked as "under-estimates", "over estimates" or as "appropriate estimates" based on a subjective assessment of how representative the study sample was of the population of interest from the description of the study design in the methods section of the reviewed paper. The study outcomes assessed as likely over- or under-estimates were used to bound plausibility ranges of the appropriate estimates (10).

A number of population groups were assessed to have appropriately representative studies of anti-HCV prevalence, including foreign-born persons aged 14-79 years old, current and former injection drug users, homeless persons who do not use injection drugs, federal and provincial inmates and residents of long-term healthcare facilities. For these groups, prevalence estimates from the group of studies ranked as "appropriate estimates" were chosen if they were from cohort studies or systematic reviews, or, in the absence of such, from studies with more accurate geographical representation. For foreign-born persons, a range of anti-HCV prevalence measures at $1.90 \%(95 \% \mathrm{Cl}: 1.30-2.60)$ (suggested by Greenaway and colleagues) were used (16). For current injection drug users, including those of Aboriginal origin and homeless people who use injection drugs, a range of anti-HCV seroprevalence at 63\%-69\% were used (Unpublished data. I-Track: Enhanced Surveillance of Risk Behaviours among People who Inject Drugs, Phases 1-3. PHAC. 2013). For former injection drug users, a range of anti-HCV seroprevalence at $28.5 \%(95 \% \mathrm{Cl}$ : 10.8-46.3) from a custom tabulation of the Cycle 1 and 2 data from the Canadian Health Measures Survey were used (Unpublished data, PHAC 2013). For homeless people who do not use injection drugs, anti-HCV seroprevalence measures in the range of $0.8 \%$ (Unpublished data E-SYS: Enhanced street youth surveillance system, Phase 6 (2009-2011). PHAC, 2013) to 3.70\% were used (17). For inmates of the federal penitentiaries, a point estimate of anti-HCV prevalence at $24.0 \%$ provided by the Correctional Service Canada for 2011 (Unpublished data. Correctional Service Canada, 2013) and a range of measures from a publication by De and colleagues at $18.10 \%-37.10 \%$ were used (18). For inmates of the provincial penitentiaries, a range of published measures of anti-HCV seroprevalence between $18.5 \%$ (19) and $28.0 \%$ were used (20). For residents of long-term care facilities, a range of published measures of anti-HCV seroprevalence between $1.4 \%(21)$ and $4.5 \%$ were used (20).

For the remaining population groups (including Aboriginal people who do not use injection drugs and Canadianborn persons of non-Aboriginal ancestry aged $0-13$ and $80+$ years old who do not use injection drugs), mid-point estimates and plausibility ranges were derived using indirect evidence on anti-HCV prevalence measures as compared to the anti-HCV prevalence estimates in populations with reliable estimates, such as rate ratios or higher or lower position in relation to anti-HCV prevalence rates measured in the comparison populations. Thus, the lower bound of the prevalence estimate $(0.03 \%)$ for $14-44$ years old from a custom tabulation of the Cycle 1 and 2 data from the Canadian Health Measures Survey (Unpublished data. PHAC,2013) was used as the upper bound for children 0 to 13 years old, while the lower bound was assigned as $0.01 \%$ and the mid-point estimated as the average of the two. For senior residents aged $80+$ years old, the mid-point and range of prevalence in 1444 years old from a custom tabulation of the Cycle 1 and 2 data from the Canadian Health Measures Survey (Unpublished data PHAC, 2013) $(0.16 \%(0.03 \%$ to $0.29 \%)$ was assigned with the understanding that it should be lower than the prevalence in $45-79$ years old $(0.93 \%(0.33 \%-1.53 \%)$ but higher than that in the age group of $0-13$ years old $(0.02 \%(0.01 \%-0.03 \%)$ (as is evidenced from a custom tabulation of the Cycle 1 and 2 data from the Canadian Health Measures Survey (Unpublished data. PHAC, 2013).

For Canadian-born persons of non-Aboriginal ancestry who do not use injection drugs aged 14-79 years old, anti$\mathrm{HCV}$ prevalence measures from a custom tabulation of the Cycle 1 and 2 data from the Canadian Health Measures Survey (Unpublished data PHAC, 2013) (0.20\% (95\% Cl: 0.10-0.30\%) were used. For Aboriginal persons who do not use injection drugs, a multiple of 2.5 (a coefficient found in the study of Uhanova and colleagues (23) times the seroprevalence rate from a custom tabulation of the Cycle 1 and 2 data from the Canadian Health Measures Survey (Unpublished data, PHAC, 2013) in Canadian-born persons of non-Aboriginal ancestry who do not use injection drugs aged 14-79 years old was used. Due to very limited data on anti-HCVpositive status awareness, a point estimate of undiagnosed chronic HCV infection from the back-calculation method was applied to the point-estimates of persons with chronic HCV infection from the workbook and backcalculation methods to calculate the range of undiagnosed persons with chronic HCV infection. 


\section{Results}

The overall prevalence of chronic HCV infection (as estimated from the back-calculation) was $0.64 \%$ or 220,697 persons in 2011. In the previous 20 years, the country's prevalence of chronic HCV infection had changed in the range of $0.6 \%$ to $0.7 \%$ (Figure 1). The highest prevalence of chronic HCV infection occurred in the birth cohort 1955-59 (1.5\%), followed by the birth cohorts 1950-54 (1.25\%), 1960-64 (1.2\%), 1965-69 (1.1\%) and 1970-74 $(0.8 \%)$. The prevalence of chronic HCV infection among those born before 1949 has declined from approximately $1 \%$ to below the overall prevalence rate in the past 20 years. The prevalence of chronic HCV infection among those born after 1965 has increased from below the overall prevalence rate to above it. The prevalence of chronic HCV infection in those born between 1950 and 1964 has remained above the overall prevalence rate throughout the 20 year period. The back-calculation method also estimated that $44 \%$ of those with chronic HCV infection were not diagnosed in 2011.

Figure 1: Estimated prevalence of chronic $\mathrm{HCV}^{1}$ infection (per 100 population) in Canada from a backcalculation model ${ }^{2}$

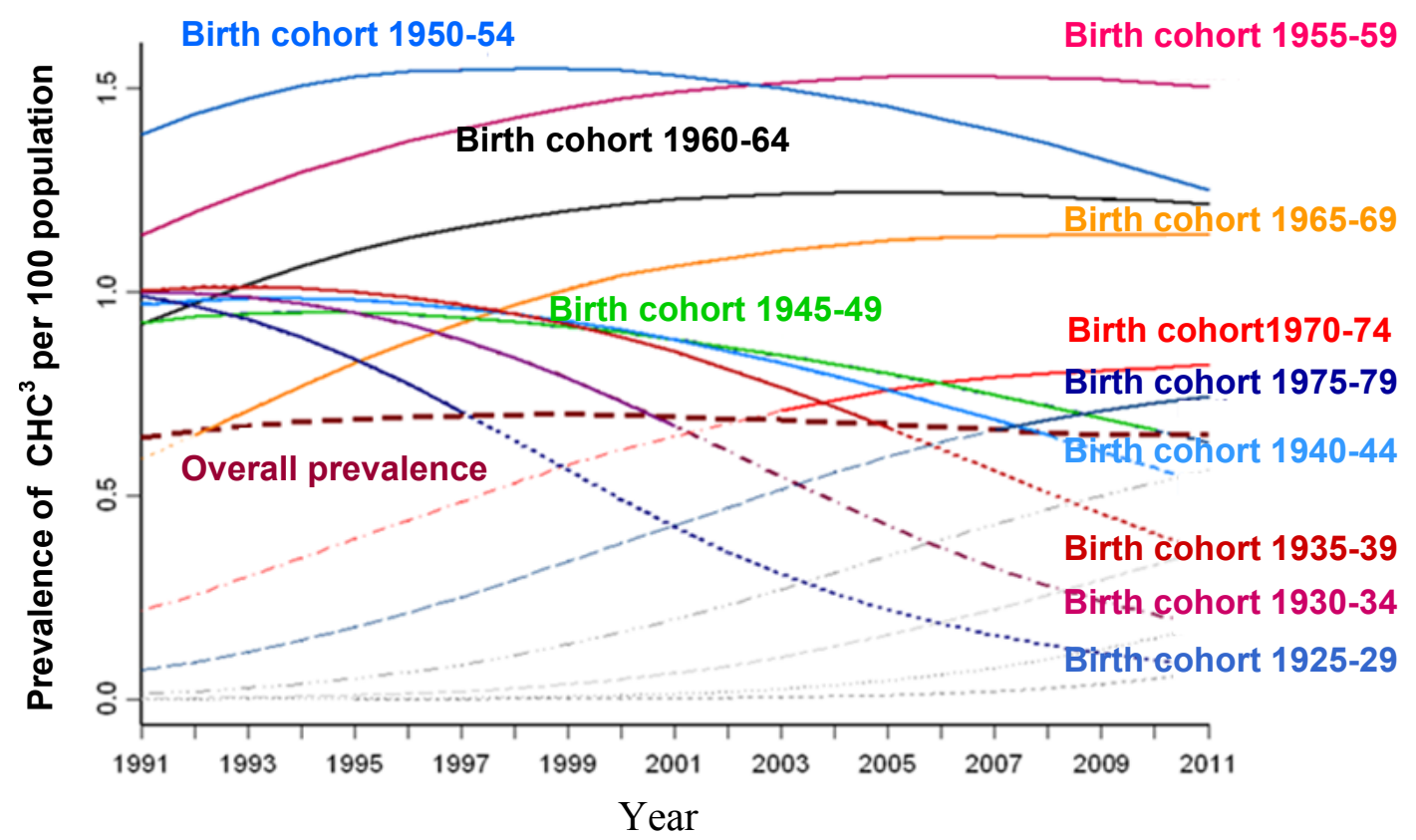

${ }^{1} \mathrm{HCV}=$ Hepatitis $\mathrm{C}$ virus

${ }^{2}$ Note: Solid lines were used to reflect the birth cohort specific prevalence when it was above the overall prevalence. Dotted lines were used for when the prevalence was below the overall estimate.

${ }^{3} \mathrm{CHC}=$ chronic Hepatitis $\mathrm{C}$

The workbook method estimated the anti-HCV prevalence in Canada in 2011 at $0.96 \%$ with a plausibility range of $0.61 \%$ to $1.34 \%$ (Table 1 ). This range translates into an estimated 332,414 persons (plausibility range (persons): 210,753 to 461,517) who were anti-HCV-positive in 2011 (Table 1). After adjusting for an HCV clearance rate of $26 \%$, the workbook method estimated $0.71 \%$ (plausibility range (\%): $0.45-0.99$ ) or 245,987 persons (plausibility range (persons): 155,957 to 341,522 ) had not cleared the virus and were considered living with chronic HCV infection in 2011. 
Table 1: Estimated prevalence and the number of anti-HCV ${ }^{1}$-positive persons with associated plausibility ranges by key population in Canada in 2011

\begin{tabular}{|c|c|c|c|c|c|c|c|c|}
\hline \multirow{2}{*}{ Population } & \multirow{2}{*}{$\begin{array}{l}\text { Sources of } \\
\text { populations } \\
\text { (reference) }\end{array}$} & \multirow{2}{*}{$\begin{array}{l}\text { Size of } \\
\text { population }\end{array}$} & \multicolumn{3}{|c|}{$\begin{array}{l}\text { Anti-HCV-positive } \\
\text { prevalence (\%) }\end{array}$} & \multicolumn{3}{|c|}{$\begin{array}{c}\text { Number of anti-HCV-positive } \\
\text { persons }\end{array}$} \\
\hline & & & $\begin{array}{c}\text { Mid- } \\
\text { Estimate }\end{array}$ & $\begin{array}{l}\text { Lower } \\
\text { bound }\end{array}$ & $\begin{array}{l}\text { Upper } \\
\text { bound }\end{array}$ & $\begin{array}{c}\text { Mid- } \\
\text { Estimate }\end{array}$ & $\begin{array}{l}\text { Lower } \\
\text { bound }\end{array}$ & $\begin{array}{l}\text { Upper } \\
\text { bound }\end{array}$ \\
\hline $\begin{array}{l}\text { Non-Aboriginal-non- } \\
\text { Immigrant-non-IDU }{ }^{3} 14- \\
79 \text { years old. }\end{array}$ & $\mathrm{uCHMS}^{4}$ & $19,855,629$ & 0.20 & 0.10 & 0.30 & 39,711 & 19,856 & 59,567 \\
\hline $\begin{array}{l}\text { male \& female } 0-13 \\
\text { years old. }\end{array}$ & $\begin{array}{l}\text { Stats Canada (30), } \\
\mathrm{CHA}^{5}(32)\end{array}$ & $5,235,834$ & $0.02^{6}$ & 0.01 & 0.03 & 1,047 & 524 & 1,571 \\
\hline $\begin{array}{l}\text { male } \& \text { female } 80+ \\
\text { years old. }\end{array}$ & $\begin{array}{l}\text { Stats Canada (30), } \\
\mathrm{CHA}^{5}(31)\end{array}$ & $1,141,489$ & $0.16^{6}$ & 0.03 & 0.29 & 1,826 & 342 & 3,310 \\
\hline $\begin{array}{l}\text { Foreign-born 14-79 } \\
\text { years old. }\end{array}$ & $\begin{array}{l}\text { Stats Canada (30), } \\
\operatorname{CIC}^{7}(32)\end{array}$ & $6,127,814$ & 1.90 & 1.30 & 2.60 & 116,428 & 79,662 & 159,323 \\
\hline Aboriginal non-IDU ${ }^{3}$ & $\begin{array}{l}\text { Stats Canada (30) } \\
\text { Remis (6) }\end{array}$ & $1,223,081$ & $0.50^{6}$ & 0.25 & 0.75 & 6,115 & 3,058 & 9,173 \\
\hline $\begin{array}{l}\text { Former IDU }{ }^{3} \text { 14-79 } \\
\text { years old. }\end{array}$ & $\mathrm{uCHMS}^{4}$, Remis (6) & 265,270 & 28.50 & 10.80 & 46.30 & 75,602 & 28,649 & 122,820 \\
\hline Current IDU ${ }^{3}$ & $\begin{array}{l}\operatorname{CCSA}^{8} \text { (33), Remis } \\
\text { (6) }\end{array}$ & 100,000 & $66.00^{6}$ & 63.00 & 69.00 & 66,000 & 63,000 & 69,000 \\
\hline Homeless non-IDU ${ }^{3}$ & $\begin{array}{l}\text { Pye (34), Laird (35), } \\
\text { ul-Track }^{9}\end{array}$ & 180,969 & $2.25^{6}$ & 0.80 & 3.70 & 4,072 & 1,448 & 6,696 \\
\hline $\begin{array}{l}\text { Federal inmates, } \\
\text { including youth }\end{array}$ & \multirow{2}{*}{$\begin{array}{l}\text { Dauvergne (36), } \\
\text { Prisonstudies.org } \\
\text { (37), UBC }{ }^{10}(38), \\
\text { prisonjustice.ca (39) }\end{array}$} & 14,556 & 24.00 & 18.10 & 37.10 & 3,493 & 2,635 & 5,400 \\
\hline $\begin{array}{l}\text { Provincial inmates, } \\
\text { including youth }\end{array}$ & & 39,942 & $23.25^{6}$ & 18.50 & 28.00 & 9,287 & 7,389 & 11,184 \\
\hline $\begin{array}{l}\text { Residents of nursing } \\
\text { homes and long-term } \\
\text { care hospitals }\end{array}$ & $\mathrm{CHA}^{5}(31)$ & 299,390 & $2.95^{6}$ & 1.40 & 4.50 & 8,832 & 4,191 & 13,473 \\
\hline Prevalence & \multirow[b]{2}{*}{ Stats Canada (30) } & \multirow[b]{2}{*}{$34,483,975$} & 0.96 & 0.61 & 1.34 & $\mathrm{n} / \mathrm{a}^{11}$ & $\mathrm{n} / \mathrm{a}^{11}$ & $\mathrm{n} / \mathrm{a}^{11}$ \\
\hline $\begin{array}{l}\text { Number of anti-HCV }{ }^{1}- \\
\text { positive }^{8}\end{array}$ & & & $\mathrm{n} / \mathrm{a}^{11}$ & $\mathrm{n} / \mathrm{a}^{11}$ & $\mathrm{n} / \mathrm{a}^{11}$ & 332,414 & 210,753 & 461,517 \\
\hline
\end{tabular}

${ }^{\mathrm{HCV}}=$ Hepatitis $\mathrm{C}$ virus

${ }^{2}$ Note: Numbers may not add up due to rounding

${ }^{3} \mathrm{IDU}=$ injection drug user

${ }^{4} \mathrm{uCHMS}=$ unpublished custom tabulation of Canadian Health Measures Survey Cycle 1 and 2 data

${ }^{5} \mathrm{CHA}=$ Canadian Healthcare Association

${ }^{6}$ Note: Calculated as an arithmetic average of the lower and upper bounds

${ }^{7} \mathrm{CIC}=$ Citizenship and Immigration Canada

${ }^{8} \mathrm{CCSA}=$ Canadian Centre on Substance Abuse

${ }^{9} \mathrm{uI}$-Track = unpublished data from I-Track (national behavioural and biological surveillance system)

${ }^{10}$ University of British Columbia

${ }^{11} \mathrm{~N} / \mathrm{A}=$ not applicable

\section{Discussion}

By combining mid-points from both methods, between $0.64 \%$ to $0.71 \%$ of the overall Canadian population (from 220,697 to 245,987 persons) were living with chronic HCV infection in Canada in $2011.44 \%$ of these individuals (ranging from 97,107 to 108,234) were likely undiagnosed. The estimated number of anti-HCV-positive persons was 332,414 (about $1 \%$ of the Canadian population) with a plausibility range from 210,753 to 461,517 .

"Hidden" populations such as former and current injection drug users and homeless people (approximately $1 \%$ of the total Canadian population) account for almost $44 \%$ of total anti-HCV-positive persons. Foreign-born populations comprise an additional 35\% of estimated anti-HCV-positive persons in Canada in 2011.

When compared with an estimated prevalence from a modelling exercise by Remis (6), which, like the backcalculation method used a Markov' multi-state disease progression model, mid-estimates of the prevalence of 
anti-HCV and chronic HCV infection changed from $0.8 \%(6)$ to $1.0 \%$ and from $0.6 \%$ (6) to $0.7 \%$ respectively. This suggests that between 2007 and 2011, changes in anti-HCV and chronic HCV infection prevalence (if any) occurred in a narrow range and that the majority of anti-HCV-positive persons and those with chronic HCV infection were within a few key populations in Canada.

These prevalence estimates are comparable with estimates from an analysis of US data (24). In addition, the estimate of hidden populations accounting for $44 \%$ of total anti-HCV-positive persons is generally comparable with the estimate of $34 \%$ for comparable populations in the US (24).

Other important findings of this analysis include that the birth group of 1950-1970 currently encompasses the bulk of chronic HCV infection in Canada and that the new estimated proportion of persons with undiagnosed chronic HCV infection in 2011 was $44 \%$. This new estimate is approximately twice as high as the one estimated by Remis for 2007 at $21 \%$ (6) and it falls between the estimates for populations which are expected to have high rates of HCV testing such as injection drug users at 20\%-43\% undiagnosed (Unpublished data. I-Track: Enhanced Surveillance of Risk Behaviours among People who Inject Drugs, Phases 1-3. PHAC. 2013) and populations expected to have lower rates of HCV testing such as hospital patients at $56 \%$ undiagnosed (25) and the weighted estimate for the Canadian household population of $14-79$ years old at $69.5 \%$ undiagnosed (7). The estimate of $44 \%$ undiagnosed is also within the ranges of the proportion undiagnosed found in Canada in inmates (28-50\%) (26), first time blood donors (42-58\% undiagnosed) (27) and men who have sex with men (44-75\% undiagnosed) (Unpublished data M-Track: Enhanced Surveillance of Risk Behaviours among Men who Have Sex with Men, Phases 1-2 PHAC 2013). It is also comparable with the US estimate of the proportion of undiagnosed with antiHCV-positive status at $50.3 \%(28)$.

The two back-calculation processes used together provided an opportunity to internally calibrate the model outputs to improve the fit with the reported data on HCV cases and cases of hepatocellular carcinoma. The CNDSS data allowed for a more accurate estimate of recent trends, younger birth cohorts and the overall magnitude of the epidemic. The hepatocellular carcinoma data allowed for a more effective model of historical trends, older birth cohorts and disease progression, in a manner similar to that used by other researchers in the field (14). The use of the two data sets through an iterative process improved the overall model and made it less dependent on the limitations of any one data set. We also cross-validated the annual HCV prevalence predicted by the model with the prevalence from independent data sources, including the Canadian Health Measures Survey 2007-2011 data (7) and the reported HCV infections among healthcare patients from the CIHI Discharge Abstract Database (29). While absolute measures of HCV prevalence differed between the above data sources (possibly due to the differences in methodology and in how outcomes and geographic representation were defined) there was general agreement in the distribution of predicted/estimated HCV prevalent cases by year of report and birth cohort as well as for temporal trends.

These estimates may be affected by both data and methodological limitations such as under-reporting of outcomes; combining anti-HCV and HCV-RNA test results into a single outcome measure; and using record-level data from six Canadian jurisdictions to make inferences about HCV prevalence for all of Canada. Other limitations are due to value judgements in grading and choosing outcome measures for specific populations; the largely English-language focus of the review; not adjusting the back-calculation model for the effect of HCV treatment; and the many assumptions used in the estimation process. The methods used to develop HCV prevalence estimates described in this paper make maximum use of available data, are based on independent data sources and, when used jointly and iteratively, may compensate for individual deficiencies. Nonetheless, we anticipate the prevalence estimates will change as new and improved data on HCV prevalence in Canadian populations becomes available. 


\section{Acknowledgements}

Public Health Agency of Canada: Anton Andonov, Tory Atwood, Margaret Bodie, Lily Fang, Margaret Gale-Rowe, Ania Kemp, Salman Klar, Jane Njihia, Susanna Ogunnaike-Cooke, Dana Paquette, Lisa Smylie, Jill Tarasuk, Stephanie Totten, Tom Wong, Qiuying Yang. Health Canada: Gregory Springer, Diego Garcia, Kathleen LydonHassan. Correction Service Canada: Jonathan Smith. Citizenship and Immigration Canada: Danielle Grondin, Dominique Massenat. Canadian Academia: Jordan Feld, Chris Greenaway, Naveed Janjua, Marina Klein, Mel Krajden, Robert Myers, Robert Remis, Morris Sherman, Rosie Thein, Julia Uhanova.

\section{Conflict of interest}

None

\section{Funding}

This work was supported by the Public Health Agency of Canada.

\section{References}

(1) Mohd Hanafiah K, Groeger J, Flaxman AD, Wiersma ST. Global epidemiology of Hepatitis C virus infection: New estimates of age-specific antibody to HCV seroprevalence. Hepatology. 2013; 57(4):1333-42.

(2) Public Health Agency of Canada. Frequently asked questions about Hepatitis C. http://www.phac-aspc.gc.ca/hepc/faqeng.php

(3) Scott JD, Gretch DR. Molecular diagnostics of Hepatitis C virus infection: A systematic review. JAMA. 2007; 297(7):72432.

(4) Shapshak P, Somboonwit C, Drumright LN, et al. Molecular and contextual markers of Hepatitis C virus and drug abuse. Mol Diagn Ther. 2009; 13(3):153-79.

(5) Giesecke J. Modern infectious disease epidemiology. Arnold, Hodder Headline Group; 2001.

(6) Remis R. Modelling the incidence and prevalence of Hepatitis C infection and its sequelae in Canada, 2007. Final report. PHAC, 2009. http://www.phac-aspc.gc.ca/sti-its-surv-epi/model/pdf/model07-eng.pdf.

(7) Rotermann M, Langlois K, Andonov A, Trubnikov M. Seroprevalence of Hepatitis B and C Virus Infections: Results from the 2007 to 2009 and 2009 to 2011 Canadian Health Measures Survey (CHMS). Health Reports. 2013; 24(11): 3-13.

(8) Edlin BR. Perspective: Test and treat this silent killer. Nature. 2011; 474:S18-19.

(9) Brookmeyer R, Gail MH. A method for obtaining short-term projections and lower bounds on the size of the AIDS epidemic. J Am Stat Assoc. 1988; 83: 301-8.

(10) Lyerta R, Gouws E, Garcia-Calleja JM et al. The 2005 workbook: An improved tool for estimating HIV prevalence in countries with low level and concentrated epidemics. Sex Transm Infect. 2006; 82:41-4.

(11) Beuffic-Burban S, Mathurin P, Valleron AJ. Modelling the past, current and future HCV burden in France: Detailed analysis and perspectives. Statistical Methods in Medical Research. 2009; 18:233-252.

(12) Sweeting MJ, De Angelis D, Brant LJ, Harris HE, Mann AG, Ramsey, ME. The burden of Hepatitis C in England. Journal of Viral Hepatitis. 2007; 14: 570-6.

(13) Thein HH, Yi Q, Dore GJ, Krahn MD. Estimation of stage-specific fibrosis progression rates in chronic Hepatitis C virus infection: a meta-analysis and meta-regression. Hepatology. 2008; 48, No. 2.

(14) Thein HH, Yi Q, Krahn MD. Estimation of progression of Canadians infected with the Hepatitis $\mathrm{C}$ virus through the blood supply, 1986-1990, fourth revision of Hepatitis C prognostic model incorporating data from the compensation claimant report. Toronto: University of Toronto; 2011.

(15) Micallef JM, Kaldor JM, Dore GJ. Spontaneous viral clearance following acute Hepatitis C infection: A systematic review of longitudinal studies. J Viral Hepatitis. 2006; 13: 34-41.

(16) Greenaway C, Ma A, Klein M, et al. Seroprevalence of chronic Hepatitis C virus infection in immigrants and refugees: A systematic review and meta-analysis. Prepared for publication, 2013. In: Klein M. Screening for HCV in immigrant populations. Presentation at the PHAC HCV Screening and Burden Workshop, October 7-8, 2013, Ottawa, ON.

(17) Moses S, Mestery K, Kaita KDE, Minuk GY. Viral Hepatitis in a Canadian street-involved population. Can J Public Health. 2002; 93:123-8. 
(18) De P, Connor N, Bouchard F, Sutherland D. HIV and Hepatitis C virus testing and seropositivity rates in Canadian federal penitentiaries: A critical opportunity for care and prevention. Can J Infect Dis Med Microbiol. 2004; 15(4): 221-5.

(19) Poulin C, Alary M, Lambert G, et al. Prevalence of HIV and Hepatitis C virus infections among inmates of Quebec provincial prisons. CMAJ. 2007; 177(3):252-6.

(20) Prefontaine RG, Chaudhary RK, Mathias RG. Analysis of risk factors associated with Hepatitis B and C infection in correctional institutions in British Columbia. Can J Infect Dis. 1994; 5(4):153-6.

(21) Simor AE, Gordon M, Bishai FR. Prevalence of Hepatitis B surface antigen, Hepatitis C antibody, and HIV-1 antibody among residents of a long-term-care facility. J Am Geriatr Soc. 1992; Mar;40(3):218-20.

(22) Chien NT, Dundoo G, Horani MH, et al. Seroprevalence of viral Hepatitis in an older nursing home population. J Am Geriatr Soc. 1999; Sep;47(9):1110-3.

(23) Uhanova J, Tate RB, Tataryn DJ, Minuk GY. The epidemiology of Hepatitis C in Canadian indigenous population. Can J Gastroenterol. 2013; 27 (6):336-40.

(24) Chak E, Talal AH, Sherman KE, et al. Hepatitis C virus infection in USA: An estimate of true prevalence. Liver Int. 2011; 31(8):1090-101

(25) Houston S, Rowe BH, Mashinter L, et al. Sentinel surveillance of HIV and Hepatitis C virus in two urban emergency departments. Can J Emerg Med. 2004; 6(2):89-96.

(26) Jafari S, Copes R, Baharlou S, et al. Tattooing and the risk of transmission of Hepatitis C: A systematic review and metaanalysis. Int J Infect Dis. 2010; Nov;14(11):e928-40.

(27) Bowker SL, Smith LJ, Rosychuk RJ, Preiksaitis JK. A review of general Hepatitis C virus lookbacks in Canada. Vox Sanguinis. 2004; 86:21-7.

(28) Denniston MM, Klevens RM, McQuillan GM, Jiles RB. Awareness of infection, knowledge of Hepatitis C, and medical follow-up among individuals testing positive for Hepatitis C: National health and nutrition examination survey $2001-2008$. Hepatology. 2012; 55:1652-61.

(29) Schanzer D, Paquette D, Lix L. Historical trends and projected hospital admissions for chronic hepatitis $C$ infection in Canada: A birth cohort analysis. Canadian Medical Association Journal Open. 2(3):E139-E144.

(30) Statistics Canada, Demography Division. Population estimates 0-100+, 1971-2012. Updated postcensal estimates, July 2012.

(31) Canadian Healthcare Association. "New Directions for Facilities-based Long-term Care, Table 2. http://www.cha.ca/wp-content/uploads/2012/11/CHA_LTC_9-22-09_eng.pdf, accessed July 11, 2013.

(32) Citizenship and Immigration Canada. Facts and figures 2012. Immigration overview. http://www.cic.gc.ca/english/resources/statistics/facts2012/permanent/01.asp.

(33) Canadian Centre on Substance Abuse. Injections Drug Use Overview. CCSA, 2013. http://www.ccsa.ca/Eng/Topics/Populations/IDU/Pages/InjectionDrugUsersOverview.aspx.

(34) Pye S. The Homeless Individuals and Families Information System (HIFIS) Initiative: Using information and communication technologies to build knowledge and understanding on homelessness, National Secretariat on Homelessness, Gatineau, Quebec, n.d., p. 1.

(35) Laird G. Shelter - Homelessness in a Growth Economy: Canada's 21st Century Paradox, Sheldon Chumir Foundation for Ethics in Leadership, Calgary, Alberta, 2007, p. 4.

(36) Dauvergne M. Adult correctional statistics in Canada, Table 1. Average counts of adults in correctional services, by type of supervision, Canada, 2010/2011, http://www.statcan.gc.ca/pub/85-002-x/2012001/article/11715-eng.htm

(37) Federally incarcerated youth $12-17$ represent $4.9 \%$ of the total number of federal inmates. From the Canada page on prisonstudies.org. http://prisonstudies.org/country/canada, accessed March 11, 2014.

(38) General Information on Canadian Prisons http://ccphe.familymed.ubc.ca/resources/general-information-on-canadianprisons/

(39) Proportion of female inmates among provincial inmates. http://www.prisonjustice.ca/politics/facts_stats.html 